\title{
Türkiye İmalat Sanayinde Gelir Değişmeleri ve Boş Zaman Tercihleri İlişkisi
}

\author{
Aynur YILDIRIM*
}

Gonca AKGÜN GÜNGÖR **

\begin{abstract}
$\ddot{O} Z$
Toplumların ekonomik yapısı, gelire ulaşmak için harcanan çalışma saatleri üzerinde etkili olmaktadır. Aynı çalışma saati ile daha fazla gelir elde eden bazı toplumlarda gelirdeki bu artış, insanların daha fazla çalışmasını teşvik ederken; bazı toplumlarda ise insanları daha az çalışmaya yöneltmekte ve boş zaman tercihlerini arttırmaktadır. Çalışmanın amacı, Türkiye ekonomisinde gelir değişmelerinin ve bu çerçevede ani bir gelir düşmesi olarak da tanımlanabilecek olan iktisadi krizlerin çalışanların boş zaman tercihleri üzerindeki etkisini, Türkiye imalat sanayi alt sektörleri üzerinden incelemektir. Çalışmada öncelikle boş zaman kavramı açıklanmış, daha sonra gelir değiş̧meleri ve boş zaman arasındaki ilişki kurulmuştur. 2003-2015 dönemindeki değişmelerin etkileri panel veri analizi yöntemi ile ekonometrik olarak test edilmiştir. Analize imalat sanayi alt sektörleri emek yoğun ve sermaye yoğun sektörler olarak iki klsma ayrllarak dahil edilmiştir. Böylece, imalat sanayi çalışanlarının gelir düzeylerinin alt gelir grubu ve üst gelir grubu olarak ayrlştırılması sağlanmıştır. Analiz sonuçlarına göre; alt gelir düzeyinde (emek-yoğun sektörler) gelir arttıkça çalışma saatleri düşerken(gelir etkisi) ; üst gelir düzeyinde (sermaye-yoğun sektörler) ise gelir artışı karşısında çalışma saatlerinin arttı̆̆ görülmüşü̈r (ikâme etkisi). Buna göre, Türkiye'de emek yoğun sektörlerde gelir etkisi; sermaye yoğun sektörlerde ise ikâme etkisinin geçerli olduğu ortaya çıkmıştır. Literatürdeki diğer çalışmalar ile karşılaştırıldığında, boş zaman tercihlerindeki farklılıkların bir sebebinin de gelir düzeyindeki farklılıklar olduğu anlaşılmıştır.
\end{abstract}

Anahtar Kelimeler: Boş zaman, ekonomik gelişme, çalışma tercihleri

JEL Sinıflandırması: O14, O43, E64

\section{Income Change and Leisure Time Preferences in Manufacturing Industry Relations in Turkey}

\begin{abstract}
The economic structure of societies has an impact on the working hours spent to generate an income. While an increase in income due to more working hours encourages people to work more in societies that generate more income with the same amount working hours, it leads people to work less and increase their leisure time preferences in some other societies. The aim of the study is examine the impact of the change in workers' income and economic crisis in the Turkish economy on leisure preferences through manufacturing sub-sectors of Turkey. In the study, firstly the concept of leisure time is explained, then the relation between income changes and leisure time is established. The effects of the changes during 2003-2015 were tested econometrically by Panel Data Analysis method. The manufacturing sub-sectors were included in the analysis in two parts as labour-intensive and capital-intensive sectors. Thus, the income levels of the employees of the manufacturing industry are separated into lower income group and upper income group. According to the results of the analysis, working hours fall as income increases at lower income levels-labour intensive sectors- (income effect) whereas working hours increase as income increases at higher
\end{abstract}

\footnotetext{
* Dr.Öğr. Üyesi, Muğla Sıtkı Koçman Ünv. Fethiye İşletme Fakültesi, Ekonomi ve Finans Bölümü, aynury@mu.edu.tr

Dr. Öğr. Üyesi, Muğla Sıtkı Koçman Ünv. İ̈BF, Uluslararası Ticaret ve Finansman Bölümü, gonca@mu.edu.tr
} 
income levels -capital intensive sectors- (substitution effect). Accordingly, in Turkey, while the income effect on labour-intensive sectors appears to be valid, the substitution effect appears to be valid in the capital-intensive sectors. Compared with other studies in the literature, it is understood that income level variance is one of the factors that affect leisure time preferences in Turkey.

Key Words : Leisure time, economic development, working time preferences

JEL Classification O14, O43, E64

\section{GíRiş}

Ülkelerin üretim yapılarında zamanla meydana gelen değişmeler, üretim faktörlerinin fayda- zahmet dengesi üzerinde de etkili olmakta ve aynı gelire sahip olmak için bazı toplumlarda daha çok çalışmak gerekirken, diğer bazı ülkelerde daha az çalışmak yeterli olabilmektedir. Bu durumda değişen ekonomik yap1 toplumların gelire ulaşmak için harcayacakları çalışma saatlerini de etkilemektedir. Ancak burada doğrusal/tek yönlü bir ilişki olduğunu söylemek kolay değildir. Aynı çalışma saati ile daha fazla gelir eden toplumların bir kısmında, bu gelir artışının sağladığı motivasyon gelirini artırmak için insanların daha fazla çalışmasına neden olduğu gibi bazı toplumlarda bireylerin tercihleri daha az çalışmaya yönelmek, boş zamanlarını artırmak şeklinde olabilmiştir.

Özellikle ABD ve Avrupa ülkeleri arasında boş zaman tercihleri konusunda görülen tercih farklılığ bu ilişkinin tek boyutlu olmadığının açık göstergesidir. 1970li yıllardan günümüze ABD'de kişi başına düşen gelirler artmasına rağmen emeğin çalışma saatleri belirgin bir şekilde yükselmişken, Avrupa ülkeleri aynı süreçte gelir artışı karşısında daha az çalışmayı tercih etmiştir.

Çalışmanın ilk kısmında gelir değişmelerinin çalışma saatleri üzerindeki etkisi teorik olarak incelenmiştir. Türkiye ekonomisinde 2003-2015 döneminde meydana gelen gelir değişmeleri ve imalat sanayi alt sektörlerinde çalışma saatlerinde meydana gelecek değişmelerin incelendiği ikinci bölümün ardından, üçüncü bölümde 2003-2015 dönemindeki değişmelerin etkileri panel veri analizi yöntemi ile ekonometrik olarak test edilmiştir.

\section{BOŞ ZAMAN VE BOŞ ZAMAN TERCIHII KAVRAMI}

Boş zaman çalışmaktan arta kalan, bağlayıcılık ve zorunluluktan uzak, kişinin özgür iradesiyle tasarrufta bulunacağı, kurumsal zorunluluklardan gelen yorgunluğun neden olduğu fiziki ve psikolojik güç kaybını tekrar kazanılmasını sağlayacak zaman dilimi olarak tanımlanmaktadır (Aytaç, 2002: 232). Boş zaman, ücretli işler, ev işleri/çocuk bakımı veya kişisel bakım için harcanmayan zaman olarak tanımlanmakta ve 18-64 yaş arasındaki kişiler için hafta başına saat olarak ölçülmektedir (Veal, 2016: 226). Diğer bir ifade ile boş zaman, işin zorlayıcı dünyasından, gevşeme, ferahlama ve de kendini salıverme durumuna bir kaçış olarak görülmektedir (Hibbins, 1996:23). Roberts'e göre ise boş zaman, tüketimcilik çerçevesinde yeni anlamlar kazanmıştır. Ona göre, boş zaman tüketimci bir yaşam alanıdır. Boş zamanın değeri de, bireylerin harcama firsatları ve tüketim performansıyla ölçülür (Roberts, 1999: 170-171). 
Boş zaman kavramı başlangıçta, serbest olma, özgürleşme, rahatlık ve gevşeme kavramlarıyla daha fazla ilişkiliyken şimdilerde bu anlamlardan büyük ölçüde uzaklaşmış, bireysel inisiyatifin, istemli tercihlerin ve özgürlüğün alanı olmaktan çıkarak kurumsal aygıtların kontrolüne aldıkları, farklı maksatlara göre organize ettikleri sınırlı kullanım sığası olan bir zaman olarak anlaşılmaktadır (Juniu;2000).

\section{İLIŞKİ}

II. GELİR DEĞISSMELERİ VE BOŞ ZAMAN ARASINDAKI

Toplumun sahip olduğu değerler yani kültür, tüketim, tasarruf, eğitim ya da iş ahlâkı gibi en temel davranış şekillerinde bireyin davranışlarına yansıyarak, karşılaştı̆̆ olaylar karşısında bireyin karar almasında ve davranışlarında onu yönlendirmektedir (Fellner, 2008: 112; Greif, 2006: 271; Kotler, Jatusrıpitak ve Maesincee, 2005: 115). Toplumda yer alan tüketim ve üretim faaliyetleri, toplumun sahip olduğu kurallara ve değerlere göre gerçekleştirilmektedir. Bazı toplumlarda tüketim eğilimi düşük, tasarruf eğilimi yüksekken; bazılarında tam tersi ekonomik davranış şekilleri ile karşılaşılabilmektedir.

Ekonomik gelişme, gelir değişmeleri ve teknolojik gelişme ile birlikte kültür, alışkanlıklar, yaşam tarzı, hayat algısı gibi toplumun alt yapı kurumlarını dönüştürerek kurumsal yapıyı değiştirirken, boş zaman algısının da değişmesine yol açmıştır. Modern yaşam düzeni içerisinde boş zamanın tüketim endüstrisinin inşa edildiği bir alana doğru dönüştüğü görülmektedir. Sanayileşmiş hatta gelişmekte olan ülkelerde görülen önemli değiş̧ikliklerden birisi de boş zamanlardaki kayda değer artıştır.

Ekonomide boş zaman, piyasa değeri olan, pazarda satış nesnesi olan, bireyi tatmin eden zevklerin getirdiği normal bir mal olarak kabul edilmektedir. Gelir ve boş zaman arasındaki ilişkide gelir; çeşitli talepleri karşılamak amacıyla mal ve hizmet almak için kullanılan satın alma gücünü ifade ederken, boş zaman gelirin sağladığı satın alma gücünün tüketildiği, harcandığı tüketim alanı olarak görülmektedir. Dolayısıyla toplumdaki boş zaman artışı tüketim malları ve eğlence aktivitelerine olan talebi de artırmaktadır.

Gelir ve boş zaman arasındaki denge, bireyin ne kadarlık gelir karşılığında bir saatlik boş zamanını feda edeceği ile ifade edilmektedir (Singh, 2016). Boş vakit geçirmek istenilen her zaman potansiyel kazançların kaybedilmesi anlamına gelmektedir, böylece geçmiş kazançlar, boş zamanın fiyatı ya da firsat maliyeti olarak belirtilmektedir (Gratton ve Taylor, 2004: 86).

Neoklasik ekonomi teorisinde bir fiyat değişikliği karşısında bireylerin gelir/boş zaman tercihlerinin ne yönde etkilendiğini ortaya koyan birbirine zit iki etki vardır. Bunlar ikame etkisi ve gelir etkisidir. Boş zamanların fiyatının artması nedeniyle daha az boş vakit geçirmek ve işe daha fazla vakit ayırmak, "ikame etkisi” olarak ifade edilmektedir. İşte harcanan zaman miktarı aynı iken toplam gelir arttığında, bu ilave gelirin bir kısmı daha az saat çalışarak daha fazla boş zaman satın almakta kullanılabilir. Ekonomi açısından normal bir mal olarak kabul edilen boş zaman talebi, gelir arttıkça artmaktadır. Buna bağlı olarak ücret 
artışıyla birlikte boş zaman talepleri de artacaktır. Bu durum "gelir etkisi” olarak adlandırılmaktadır. Dolayısıyla, zıt yönlerde çeken gelir ve ikâme etkileri etki nedeniyle boş zaman talebindeki net etki belirsizdir (Gratton ve Taylor, 2004: 86).

Emek gelirleri üzerindeki yüksek oranlı vergiler, insanları çalışmak yerine boş zaman tercihine doğru yön değiştirmeye teşvik eder. Vergi oranları (sabit olmadığ1 varsayıldığında) emek arzını etkilemektedir. Eğer emek geliri üzerindeki vergi oranlarının gelecekte daha yüksek olacağı beklenirse, insanlar bu anda daha düşük tüketim/gelir bileşimini seçer ve işgücü arzı yüksek olur (Mocan ve Pogorelova, 2015: 23; Prescott, 2004). İşgücü farklılıklarını açıklamakta verginin temel faktör olduğu bulgusu önemlidir. Çünkü, vergilerdeki azalma ekonomik faaliyetlerde önemli bir artış yaratabilir. Bu önemli düzenlemeler yerli üretimin rolünü ve işçi sendikalarını içermektedir (Mocan ve Pogorelova, 2015).

Toplumların boş zaman tercihleri incelendiğinde kayda değer farklılıklar olduğu görülmektedir. Ekonomik gelişmenin bazı toplumlarda çalışma süresinde artışa yol açtığı görülürken, bazı toplumlarda ise boş zaman tercihlerinde artışa yol açtığı anlaşılmaktadır. 2012 yılında ABD'deki işçiler yıllık ortalama 1750 saat çalışmışken, Almanya'daki işçiler bu rakamdan \%17, Fransa'da \%15, Belçika'da \%9 daha az çalışmıştır (Mocan ve Pogorelova, 2015). ABD’deki işçilerin Avrupa'daki işçilerden daha fazla çalışmasının nedenleri açıklamaya çalışan önemli bir literatür vardır. Gelir düzeyi farklılıklarının yanı sıra, ülkelerin emek üzerinden aldıkları vergi farklılıklarının, Protestan ahlakı örneğinde olduğu gibi kurumsal faktörlerin, sendikalaşma düzeylerindeki farklılıkların, emek piyasası süzenlemeleri, toplumsal hareketlilik için sağlanan firsatlardaki farklılıklar ile toplumsal ağların yoğunluk ve niteliğindeki farklılıklarının üzerinde durulmaktadır (Prescott, 2004; Mocan ve Pogorelova, 2015; Kozaryn, 2011; Weber, Parsons ve Tawney, 2003).

ABD’deki işçilerin Avrupa'daki işçilerden daha fazla çalışmasının nedenleri açıklanırken sadece farklı kültürlere başvurulması gerçekçi olmamaktadır. I Dünya Savaşı'na kadar çalışan başına çalışma saatleri Fransa ve Almanya dahil çoğu Avrupa ülkesine göre ABD'de aslında daha düşük iken, daha sonra, Avrupa ve ABD'de çalışan başına çalışma saatleri aynı olmuş; 1960'ların sonuna kadar çalışma saatleri Avrupa'da ABD'den biraz daha fazla düşmeye başlamıştır (Huberman, 2004).

ABD’deki işçilerin Avrupa'daki işçilerden daha fazla çalışmasının nedeni olarak, emek üzerinden alınan vergi oranlarının farklı olması da gösterilmiștir (Prescott, 2004: 6). Amerika'da Avrupa'ya göre daha düşük vergi oranları bulunmaktadır ve bu nedenle Amerika'daki işçiler Avrupa'daki işçilere göre daha çok çalışarak daha fazla ödemektedirler. Amerika'daki iş eşitsizliği, daha uzun saatler çalışmayı teşvik eden ücret farklılıklarına yol açmaktadır. $\mathrm{Bu}$ teşvikler Avrupa'da o kadar güçlü değildir (Michelacci, 2007). İsveç ve ABD için yapılan çalışmada ABD'de vergi oranlarının düşük, İsveç'te ise yüksek olduğu ifade edilmiştir. Vergiler, hizmetten ve emekten alınan vergiler şeklinde üretime bağlanmıştır. Buna göre vergi oranlarının düşük olması ABD’de üretimi, 
çalışmayı çekici hale getirmektedir. Vergi oranlarının yüksek olduğu İsveç’te emek gelirleri üzerinden alınan vergilerin yüksek olması ise piyasada çalışma yerine boş zaman tercihini artırmakla sonuçlanmaktadır (Olovsson, 2009).

\section{TÜRKIYE IMALAT SANAYINDE GELIR DEĞIŞMELERI} VE BOŞ ZAMAN İLIŞSKİsi

Türkiye imalat sanayinde gelir değişmeleri ve boş zaman tercihlerini inceleyebilmek amacıyla öncelikle imalat sanayi alt sektörleri emek yoğun ve sermaye yoğun sektörler olarak iki kısma ayrılmıştır. Böylece, imalat sanayi çalışanlarının gelir düzeylerinin alt gelir grubu ve üst gelir grubu olarak ayrıştırılması sağlanmıştır. Tablo1'de imalat sanayi alt sektörlerinin emek ve sermaye yoğunlukları açısından sınıflandırılması görülmektedir.

Tablo 1: İmalat Sanayi Alt Sektörlerinin Emek ve Sermaye Yoğunluğuna Göre Sinıflandırılması

\begin{tabular}{|c|c|}
\hline \multicolumn{2}{|r|}{ Emek Yoğun Sektörler } \\
\hline Sektör Kodu & Sektör Adı \\
\hline 10 & G1da ürünlerinin imalatı \\
\hline 11 & İçeceklerin imalatı \\
\hline 12 & Tütün ürünleri imalatı \\
\hline 13 & Tekstil ürünlerinin imalatı \\
\hline 14 & Giyim eşyalarının imalatı \\
\hline 15 & Deri ve ilgili ürünlerin imalatı \\
\hline 16 & $\begin{array}{l}\text { Ağaç, ağaç ürünleri ve mantar ürünleri imalatı (mobilya hariç); saz, saman ve benzeri } \\
\text { malzemelerden örülerek yapılan eşyaların imalatı }\end{array}$ \\
\hline 17 & Kağıt ve kağıt ürünlerinin imalatı \\
\hline 18 & Kayıtlı medyanın basılması ve çoğaltılması \\
\hline 23 & Diğer metalik olmayan mineral ürünlerin imalatı \\
\hline 24 & Ana metal sanayii \\
\hline 31 & Mobilya imalatı \\
\hline 32 & Diğer imalatlar \\
\hline \multicolumn{2}{|r|}{ Sermaye Yoğun Sektörler } \\
\hline Sektör Kodu & Sektör Adı \\
\hline 19 & Kok kömürü ve rafine edilmiş petrol ürünleri imalatı \\
\hline 20 & Kimyasalların ve kimyasal ürünlerin imalatı \\
\hline 21 & Temel eczacılık ürünlerinin ve eczacılığa ilişkin malzemelerin imalatı \\
\hline 22 & Kauçuk ve plastik ürünlerin imalatı \\
\hline 25 & Fabrikasyon metal ürünleri imalatı (makine ve teçhizat hariç) \\
\hline 26 & Bilgisayarların, elektronik ve optik ürünlerin imalatı \\
\hline 27 & Elektrikli teçhizat imalatı \\
\hline 28 & Başka yerde sınıflandırılmamış makine ve ekipman imalatı \\
\hline 29 & Motorlu kara taşıtı, treyler (römork) ve yarı treyler (yarı römork) imalatı \\
\hline 30 & Diğer ulaşım araçlarının imalatı \\
\hline
\end{tabular}


*Tarafımızca söz konusu dönemde sektörlerin birim emek başına düşen sabit sermaye yatırımlarına yapılan ilaveler verileri ve üretim değeri başına düşen ücret verileri ile uluslararası kurumlar ve akademik çalışmalarda kullanılan sınıflamalar birlikte dikkate alınarak mevcut sınıflama oluşturulmuştur. Detaylı bilgi için bkz. Akgün Güngör, G. (2015), "Küreselleşme Sürecinde Türkiye'de Karşılaştırmalı Üstünlüklerin Kaleydoskopik Yapısı: İmalat Sanayi Örneği”, Uluslararası Sosyal Araştırmalar Dergisi, 8(41), 1071-1086.

Tablo1'de yer verilen sinıflandırmaya göre, imalat sanayi alt sektörlerinde çalışanların gelir düzeyleri Tablo 2 ve Tablo 3'te gösterilmiştir. Emek yoğun sektörlerde çalışanların gelir düzeyini yansıtan Tablo 2'ye göre emek yoğun sektörlerde istihdam edilenlerin saat başına ücretleri inceleme dönemini kapsayan 2003-2015 döneminin başında ortalama 3.12 Dolar iken yıllar içinde dalgalı bir seyir izleyerek, 2015 yılında ortalama 5.32 Dolara yükseldiği görülmektedir.

Tablo 2: Emek Yoğun Sektörlerde Çalışanların Gelir Düzeyi (Saat Başına Ücret \$)

\begin{tabular}{|c|c|c|c|c|c|c|c|c|c|c|c|c|c|c|}
\hline Ylllar & $\mathbf{1 0}$ & $\mathbf{1 1}$ & $\mathbf{1 2}$ & $\mathbf{1 3}$ & $\mathbf{1 4}$ & $\mathbf{1 5}$ & $\mathbf{1 6}$ & $\mathbf{1 7}$ & $\mathbf{1 8}$ & $\mathbf{2 3}$ & $\mathbf{2 4}$ & $\mathbf{3 1}$ & $\mathbf{3 2}$ & Ort \\
\hline $\mathbf{2 0 0 3}$ & 2,54 & 5,66 & 8,50 & 1,97 & 1,59 & 1,46 & 1,61 & 4,39 & 1,92 & 2,87 & 4,67 & 1,58 & 1,86 & $\mathbf{3 , 1 2}$ \\
\hline $\mathbf{2 0 0 4}$ & $\mathbf{2}, 33$ & 5,53 & 6,84 & 2,70 & 2,09 & 2,05 & 2,12 & 3,94 & 2,62 & 3,55 & 5,57 & 2,03 & 2,32 & $\mathbf{3 , 4 4}$ \\
\hline $\mathbf{2 0 0 5}$ & 4,02 & 6,26 & 9,21 & 3,12 & 2,48 & 2,01 & 2,17 & 4,83 & 3,35 & 4,10 & 7,13 & 2,31 & 2,69 & $\mathbf{4 , 1 3}$ \\
\hline $\mathbf{2 0 0 6}$ & 3,98 & 6,87 & 9,01 & 3,03 & 2,52 & 2,41 & 2,58 & 4,51 & 3,38 & 4,24 & 6,45 & 2,37 & 2,83 & $\mathbf{4 , 1 7}$ \\
\hline $\mathbf{2 0 0 7}$ & 4,90 & 8,19 & 10,89 & 3,51 & 2,90 & 2,80 & 2,93 & 5,31 & 3,97 & 4,89 & 7,74 & 2,95 & 3,28 & $\mathbf{4 , 9 4}$ \\
\hline $\mathbf{2 0 0 8}$ & 5,45 & 8,91 & 10,93 & 3,84 & 3,24 & 3,09 & 3,33 & 6,03 & 4,13 & 5,32 & 8,39 & 3,29 & 3,58 & $\mathbf{5 , 3 5}$ \\
\hline $\mathbf{2 0 0 9}$ & 4,69 & 7,57 & 8,85 & 3,40 & 2,91 & 2,78 & 3,20 & 5,47 & 3,69 & 4,89 & 7,40 & 2,96 & 3,33 & $\mathbf{4 , 7 0}$ \\
\hline $\mathbf{2 0 1 0}$ & 5,09 & 8,26 & 17,68 & 3,75 & 3,33 & 3,07 & 3,61 & 5,82 & 4,24 & 5,20 & 8,17 & 3,27 & 3,66 & $\mathbf{5 , 7 8}$ \\
\hline $\mathbf{2 0 1 1}$ & 4,83 & 8,34 & 14,25 & 3,66 & 3,18 & 3,18 & 3,60 & 5,76 & 3,91 & 5,00 & 8,33 & 3,10 & 3,72 & $\mathbf{5 , 4 5}$ \\
\hline $\mathbf{2 0 1 2}$ & 4,82 & 8,64 & 16,29 & 3,78 & 3,30 & 3,18 & 3,85 & 6,08 & 4,17 & 5,17 & 8,08 & 3,32 & 3,84 & $\mathbf{5 , 7 3}$ \\
\hline $\mathbf{2 0 1 3}$ & 4,94 & 8,76 & 18,05 & 4,19 & 3,54 & 3,43 & 3,96 & 6,37 & 4,33 & 5,19 & 8,53 & 3,62 & 4,20 & $\mathbf{6 , 0 9}$ \\
\hline $\mathbf{2 0 1 4}$ & 4,83 & 8,38 & 19,74 & 4,08 & 3,45 & 3,40 & 3,98 & 5,94 & 3,88 & 5,19 & 8,08 & 3,62 & 3,86 & $\mathbf{6 , 0 3}$ \\
\hline $\mathbf{2 0 1 5}$ & 4,34 & 7,53 & 15,71 & 3,76 & 3,08 & 3,17 & 3,70 & 5,28 & 3,91 & 4,71 & 7,16 & 3,25 & 3,59 & $\mathbf{5 , 3 2}$ \\
\hline
\end{tabular}

Tablo 3 ise, sermaye yoğun sektörlerde çalışanların gelir düzeyini yansıtmaktadır. Tabloya göre, sermaye yoğun sektörlerde istihdam edilenlerin saat başına ücretleri 2003 yılında ortalama 5.09 Dolar iken, yine yıllar içinde dalgalı bir seyir izlediği ve 2015 yılına gelindiğinde çalışanların gelir düzeyinin ortalama 7.86 Dolara yükseldiği görülmektedir. Emek ve sermaye yoğun sektörlerde çalışanların gelir düzeyleri karşılaştırıldığında, emek yoğun sektörlerdeki gelir düzeylerinin sermaye yoğun sektörlere göre daha düşük (sermaye yoğun sektörlerdeki gelir düzeylerinin emek yoğun sektörlere göre daha yüksek) olduğu görülmektedir. Buna bağlı olarak, emek yoğun sektörlerin alt gelir düzeyini; sermaye yoğun sektörlerin ise üst gelir düzeyini temsil ettiği söylenebilmektedir.

Tablo 3: Sermaye Yoğun Sektörlerde Çalışanların Gelir Düzeyi (Saat Başına Ücret \$)

\begin{tabular}{|c|c|c|c|c|c|c|c|c|c|c|c|}
\hline Yillar & $\mathbf{1 9}$ & $\mathbf{2 0}$ & $\mathbf{2 1}$ & $\mathbf{2 2}$ & $\mathbf{2 5}$ & $\mathbf{2 6}$ & $\mathbf{2 7}$ & $\mathbf{2 8}$ & $\mathbf{2 9}$ & $\mathbf{3 0}$ & Ort. \\
\hline $\mathbf{2 0 0 3}$ & 10,63 & 5,51 & 9,41 & 2,41 & 2,15 & 4,54 & 3,96 & 2,25 & 4,47 & 5,56 & $\mathbf{5 , 0 9}$ \\
\hline $\mathbf{2 0 0 4}$ & 16,32 & 6,44 & 10,54 & 3,18 & 2,78 & 5,63 & 4,89 & 2,88 & 5,52 & 5,94 & $\mathbf{6 , 4 1}$ \\
\hline
\end{tabular}




\begin{tabular}{|l|l|l|l|l|l|l|l|l|l|l|l|}
\hline $\mathbf{2 0 0 5}$ & 17,18 & 6,76 & 12,55 & 3,86 & 3,20 & 7,51 & 5,60 & 3,37 & 6,43 & 6,17 & $\mathbf{7 , 2 6}$ \\
\hline $\mathbf{2 0 0 6}$ & 18,54 & 7,23 & 12,81 & 3,72 & 3,22 & 6,60 & 5,76 & 3,61 & 6,06 & 6,14 & $\mathbf{7 , 3 7}$ \\
\hline $\mathbf{2 0 0 7}$ & 20,93 & 8,75 & 14,64 & 4,56 & 3,81 & 8,48 & 6,50 & 4,27 & 7,38 & 7,31 & $\mathbf{8 , 6 6}$ \\
\hline $\mathbf{2 0 0 8}$ & 23,12 & 9,82 & 16,38 & 5,16 & 4,25 & 9,30 & 7,40 & 4,75 & 7,78 & 7,84 & $\mathbf{9 , 5 8}$ \\
\hline $\mathbf{2 0 0 9}$ & 18,11 & 8,27 & 15,06 & 4,53 & 3,91 & 7,34 & 6,81 & 4,43 & 7,09 & 7,17 & $\mathbf{8 , 2 7}$ \\
\hline $\mathbf{2 0 1 0}$ & 17,58 & 8,98 & 16,55 & 5,12 & 4,34 & 8,78 & 7,11 & 4,86 & 8,05 & 9,22 & $\mathbf{9 , 0 6}$ \\
\hline $\mathbf{2 0 1 1}$ & 16,44 & 8,55 & 15,50 & 4,89 & 4,32 & 8,86 & 7,03 & 4,87 & 7,55 & 9,94 & $\mathbf{8 , 8 0}$ \\
\hline $\mathbf{2 0 1 2}$ & 17,80 & 8,64 & 14,03 & 4,93 & 4,36 & 8,54 & 7,17 & 5,28 & 7,58 & 10,92 & $\mathbf{8 , 9 3}$ \\
\hline $\mathbf{2 0 1 3}$ & 18,03 & 9,26 & 13,92 & 5,14 & 4,78 & 9,65 & 7,33 & 5,49 & 7,82 & 10,98 & $\mathbf{9 , 2 4}$ \\
\hline $\mathbf{2 0 1 4}$ & 17,35 & 8,76 & 11,74 & 5,05 & 4,63 & 8,93 & 7,04 & 5,61 & 7,43 & 10,50 & $\mathbf{8 , 7 0}$ \\
\hline $\mathbf{2 0 1 5}$ & 15,84 & 8,16 & 10,73 & 4,62 & 4,29 & 7,58 & 6,14 & 5,03 & 6,90 & 9,33 & $\mathbf{7 , 8 6}$ \\
\hline
\end{tabular}

Emek ve sermaye yoğun sektörlerde çalışanların gelir düzeyleri arasındaki farkı daha net gösterebilmek için oluşturulan Grafik 1, sermaye yoğun sektörlerde çalışanların gelir düzeylerinin emek yoğun sektörlerde çalışanlara göre daha yüksek olduğunu bir kez daha ortaya koymaktadır.

Grafik 1: Türkiye İmalat Sanayinde Çalışanların Gelir Düzeyi(2003-2015)

(Saat Başına Ücret \$)

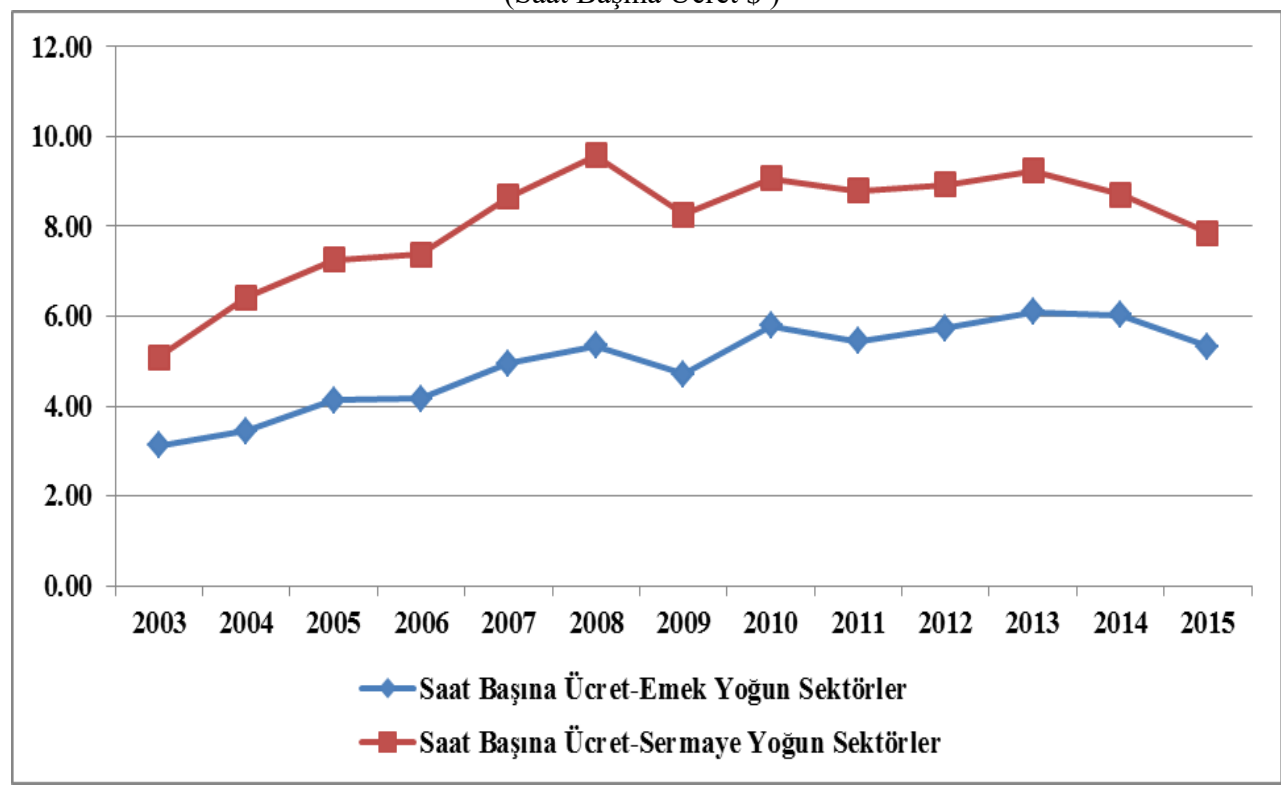

\section{Literatür Taraması}

Boş zaman tercihi üzerine Kozaryn (2011) tarafından gerçekleştirilen çalışmada, Dünya Değerler Araştırması (WSS), Eurobarometer ve Genel Sosyal Anketlerine ait veriler kullanılmış ve Amerikalıların Avrupalılardan daha fazla çalıştığı sonucuna ulaşılmıştır. Aynı çalışma, çalışma saatleri arttıkça 
Amerikalıların Avrupalılardan daha fazla mutlu olduğunu ortaya koymuştur. Benzer şekilde, Olovsson (2009), ABD'deki çalışma saatlerinin Avrupa ülkelerinden yaklaşık \%10 daha fazla olduğunu; Prescott (2004) ise, Amerikalıların Almanlar, Fransızlar ve İtalyanlar'dan \%50 daha fazla çalışıyor olduğunu göstermiştir. Prescott (2004)'a göre, Avrupa'da vergi oranlarının azaltılması çalışma saatleri ve refah üzerinde pozitif katkılarda bulunacaktır.

Mocan ve Pogorelova (2015), Dünya Değerler Araştırması (WVS) ve Avrupa Değerler Çalışması (EVS) verilerini kullanarak, 26 Avrupa ülkesi için 200-2012 dönemini kapsayacak şekilde yaptıkları incelemede, cinsiyete göre vergi oranlarının ve boş zaman kültürünün işgücüne katılma oranı üzerindeki etkilerini incelemişlerdir. Çalışmanın sonucu, kadınlar için hem vergi hem de boş zaman kültürünün işgücüne katılma oranını ve çalışma saatlerini etkilediğini ortaya koymuştur. Aynı çalışma, erkekler için ise, vergilerin işgücü arzını yoğun ve geniş bir marjda etkilediğini, boş zaman kültürünün ise işgücü arzı üzerinde etkisinin olmadığını göstermiştir. Kişi başına haftalık çalışma saatlerinin ABD'de Avrupa ülkelerine göre daha fazla olduğu Alesina, Glaeser, ve Sacerdote (2006) tarafindan yapılan çalışmayla da desteklenmiştir.

Dünya Değerler Araştırması (WSS) anket verileri üzerinden yapılan çalışmaya göre gelir eşitsizliği ve boş zaman miktarı arasında negatif ilişki vardır. Boş zaman miktarı ve kültürel aktivitelere katılım oranına bakıldığında, daha eşit düzeyde olan ülkelerin daha çok boş zamanı ve kültürel aktivitelere katılım oranları daha yüksektir Veal (2016). Ayrıca yine Dünya Değerler Araştırması (WSS) anket verileri, Avrupa Birliği üyesi ülkelerde boş zaman tercihi üzerine yapılan çalışmada, Monostori (2009) tarafından da kullanılmıştır. Söz konusu çalışmada, Avrupa ülkelerinde boş zamanın çalışmaktan daha değerli olduğu ortaya konmuştur.

Konu ile ilgili yapılan birçok çalışmada Avrupa ülkelerinde çalışma saatlerinin daha kısa olduğu belirtilirken, İngiltere'de uzun çalışma saatleri istemeyen işçilerin birçoğunun çalışma saatlerinin uygulamada uzun olduğu belirtilmiştir (Wheatley, Hardill ve Philp, 2011).

\section{VERI VE YÖNTEM}

Çalışmanın uygulama kısmında Türkiye ekonomisinde gelir değişmelerinin ve iktisadi krizlerin çalışanların boş zaman tercihleri üzerindeki etkisini ölçmek için, Türkiye imalat sanayi alt sektörleri temel alınmıştır. İmalat sanayi alt sektörleri emek yoğun ve sermaye yoğun sektörler olarak iki kısma ayrılarak analize dahil edilmiştir. Böylece, imalat sanayi çalışanlarının gelir düzeylerinin alt gelir grubu ve üst gelir grubu olarak ayrıştırılması sağlanmıştır. 2003-2015 yılları arasındaki 13 yıllık zaman dilimini kapsayan çalışma verilerinin derlenmesinde TÜIKK istatistiklerinden yararlanılmıştır. Gelir değişmelerinin boş zaman tercihleri üzerindeki etkisini göstermek temel çalışma amacımız olduğu için, küresel çapta faktör gelirlerini etkileyen 2008 krizinin boş zaman tercihleri üzerindeki etkisini ölçmek önemlidir. Bu çerçevede 2008 krizinin etkilerini 
göstermek amacıyla kukla değişken kullanılmıştır. Tablo 6'da çalışmada kullanılan değişkenler gösterilmiştir.

Tablo 6: Analizde Kullanılan Değişkenler

\begin{tabular}{|l|l|}
\hline Değişken & Açıklama \\
\hline Kişi Başına Düşen Çalışma Saatleri & Aylık Çalışma Saatleri / Ücretli Çalışan Sayısı \\
\hline Saat Başına Ücret (\$-Aylık) & Aylık Ücret / Çalışma Saati \\
\hline İhracat Oranı & İhracat / Üretim Değeri \\
\hline Kriz (Kukla Değişken) & 2008 Yılı Kukla Değişken Olarak Analize Dahil Edilmiştir. \\
\hline
\end{tabular}

Panel veri analizi yönteminin kullanılmasıyla yapılan ölçümler için Stata 9 paket programından yararlanılmıştır. Analizde bağımlı değişken kişi başına düşen çalışma saatleri iken; bağımsız değişkenler saat başına ücret, ihracat oranı ve 2008 küresel krizi (Kriz) kukla değişkenidir. Çalışanların gelirlerindeki değişmelerin ve 2008 krizinin çalışanların boş zaman tercihi üzerindeki etkileri, emek yoğun ve sermaye yoğun sektörlerde iki farklı model kurularak analiz edilmiştir. Kurulan ekonometrik modelde sahte regresyon probleminin olmaması için modelde yer alacak tüm değişkenlerin durağan olması gerekmektedir. $\mathrm{Bu}$ amaçla, emek yoğun sektörlerin yer aldığı ilk modelde uygun durağanlık analizine karar verebilmek için öncelikle yatay kesit bağımlılı̆̆1 testi yapılmıştır. Ekonometrik analizlerde heteroskedasite problemi yatay kesit verilerle çalışma yapılırken karşılaşılan bir durumdur (Tatoğlu, 2013: 208-210). Modelde birimlere göre heteroskedasitenin var olup olmadığı Friedman Testi ile sınanmıştır. Test sonucuna göre (testin olasılık değeri $(0.0000)<0.05)$, varyansın birimlere göre değiştiği anlaşılmış ve dolayısıyla birimlere göre heteroskedasite olduğu sonucuna varılmıştır. Bu nedenle, birimlerarası korelasyonu dikkate alan ikinci kuşak birim kök testlerinden Pesaran Panel Birim Kök Testi kullanılmıştır. Pesaran'ın CADF Testi sonuçları Tablo 7'de verilmektedir.

Tablo 7: Pesaran’ın CADF Birim Kök Testi Sonuçları

\begin{tabular}{|l|lllccc|}
\hline Değişkenler & t-bar & cv10 & cv5 & cv1 & Z[t-bar] & P-değeri \\
\hline Kişi Baş. Çalışma Saati I(0) & -3.914 & -2.160 & -2.280 & -2.520 & -7.225 & $0.000^{*}$ \\
\hline \hline Saat Başına Ücret I(0) & -2.550 & -2.160 & -2.280 & -2.520 & -2.712 & $0.003^{*}$ \\
\hline \hline İhracat Oranı I(0) & -0.772 & -2.160 & -2.280 & -2.520 & 3.168 & 0.999 \\
İhracat Oranı I(1) & -1.547 & -2.160 & -2.280 & -2.520 & 0.607 & 0.728 \\
İhracat Oranı I(2) & -2.346 & -2.160 & -2.280 & -2.520 & -2.036 & $0.021^{*}$ \\
\hline
\end{tabular}

*\%0,05 anlamlılık düzeyinde durağandır.

Pesaran'ın birim kök testi doğrultusunda, bağımlı değişken kişi başına düşen çalışma saati ile bağımsız değişken saat başına ücret düzeyden durağandır. İhracat oranı değişkeninin ise, ikinci derecen durağan olduğundan, değişkeninin ikinci dereceden farkları alınarak modele eklenmiştir. Durağan verilerle model yeniden kurularak analiz tekrarlanmıştır. Panel veri analizinde birey etkilerini görmek için kullanılan sabit etki (fixed effect) ve rassal etki (random effect) modellerinden hangisinin seçileceği Hausman testi çerçevesinde belirlenen bir sorundur (Tatoğlu, 2013: 179). Emek yoğun sektörler için uygulanan Hausman 
testinin sonuçları, $(08683>0.05)$ rassal etkiler tahmincisinin tutarlı olduğunu ortaya koymuştur.

Ekonometrik analizlerde, otokorelasyon problemine yatay kesit verilerinde rastlansa da uygulamada daha çok zaman serilerinde karşılaşılan bir durumdur. Otokorelasyon, çoklu regresyon analizinde hata teriminin birbirini izleyen değerleri arasında ilişki bulunması halidir. $\mathrm{Bu}$ durum, genel doğrusal regresyon modelinin önemli bir varsayımından sapmadır. Genel doğrusal regresyon modeli varsayımının gereği olarak, hata terimleri arasında bir ilişki yoktur. Çalışmamızda, rassal etkiler üzerinden kurulan modelimizde otokorelasyonun var olup olmadığı Baltagi-Wu'nun LBI testleri ile sınanmıştır. Literatürde kritik değerler verilmemesine rağmen, değer 2'den küçükse otokorelasyonun önemli olduğu yorumu yapılmaktadır (Tatoğlu, 2013:214). Buna göre Baltagi-Wu LBI test sonucu (Durbin-Wats Baltagi-Wu LBI = 1.9167165, Baltagi-Wu LBI = 1.9167165) şeklinde olup, her iki test için de değerler 2'den küçük olduğu için otokorelasyonun olduğu yorumu yapılabilmektedir.

Rassal etkiler modelinde birimlere göre heteroskedasitenin var olup olmadığı Levene, Brown ve Forsythe'nin testleri kullanılarak sınanmıştır. Levene, Brown ve Forsythe'nin test istatistikleri, emek yoğun sektörler için (W0, W50, W10) $(12,117)$ serbestlik dereceli Snedecor F tablosu ile karşılaştıııldığında, "birimlerin varyansları eşittir" şeklinde kurulan H0 hipotezi reddedilmektedir (W0=0.001, W50=0.075, W10=0.002). Bu durumda kurulan modellerde heteroskedasite olduğu anlaşılmaktadır.

Rassal etkiler üzerinden kurulan model için yapılan testlerin sonucuna göre birimler arası korelasyon, heteroskedasite ve otokorelasyon olması nedeniyle, bu problemleri ortadan kaldıran düzeltme modeli Parks-Kmenta Tahmincisi (Esnek Genelleştirilmiş En Küçük Kareler Yöntemi) kullanılmıştır. Buna göre, emek yoğun sektörler için elde edilen tahmin sonuçlarına Tablo 8'de yer verilmiştir.

Tablo 8: Emek Yoğun Sektörlerde Gelir Düzeyinin Çalışma Saatleri Üzerindeki Etkisi

\begin{tabular}{|l|c|c|}
\hline Bağımlı Değişken: Çalışma Saatleri & \multicolumn{2}{|c|}{$\begin{array}{c}\mathbf{t} \\
(\mathbf{P}>|\mathbf{t}|)\end{array}$} \\
\hline Bağımsız Değişkenler & $\begin{array}{c}\text { Katsayı } \\
\text { (Standart Hata) }\end{array}$ & -5.28 \\
\hline \multirow{2}{*}{ Saat Başına Ücretler } & $-\mathbf{0 . 0 0 3 7}$ & $(0.000)^{*}$ \\
\hline \multirow{2}{*}{ Ihracat Oranı } & $(0.0007)$ & 6.85 \\
& $\mathbf{0 . 0 0 0 1}$ & $(0.000)^{*}$ \\
\hline \multirow{2}{*}{ Kriz (Kukla Değişken) } & $(0.0000)$ & 4.49 \\
& $\mathbf{0 . 0 0 8 5}$ & $(0.000)^{*}$ \\
\hline
\end{tabular}

*\%0,05 düzeyinde istatistiksel olarak anlamlıdır.

Tablo 8'de verilen analiz sonuçlarına göre, saat başına ücretler ve çalışma saatleri arasında istatistiksel olarak anlamlı ve negatif bir ilişki bulunmuştur. Diğer bir ifade ile emek yoğun sektörlerde saat başına ücretlerde meydana gelecek \%1'lik artışın, çalışma saatlerini \% 0.0037 düşürdüğg̈ görülmektedir. Çalışmanın teorik kısmında da açıklandığı gibi, bu durum gelir etkisi olarak adlandırılmaktadır. Dolayısıyla, Türkiye imalat sanayi üzerinden yapılan analiz sonuçları, emek yoğun sektörlerde gelir etkisinin hâkim olduğunu, gelir düzeyinde meydana gelen artışların çalışma saatlerini azalttığını ortaya koymuştur. 
Krizlerin çalışma hayatı dolayısıyla boş zaman tercihleri üzerinde etkisinin olup olmadığını tespit edebilmek amacıyla, çalışmamızda 2008 Küresel Krizi kukla değişken olarak analize dahil edilmiştir. Tablo 8'de verilen analiz sonuçlarına göre, krizin çalışma saatleri üzerinde istatistiksel olarak anlamlı ve pozitif (0.0085) etkisinin olduğu görülmektedir. Dolayısıyla kişilerin kriz yıllarında (2008 yılından sonra) daha fazla çalışma eğiliminde oldukları söylenebilmektedir. Buna göre, ihracat oranındaki artışın, gelir düzeyinde yaratacağı artışa paralel olarak çalışma saatlerinde artış yarattığı söylenebilmektedir. Analiz sonuçlarına göre, ihracat oranı değişkeninde meydana gelecek \%1'lik artış, çalışma saatlerini $\% 0.0001$ arttırmaktadır.

Diğer taraftan ekonomik krizlerin doğal bir sonucu işsizlik oranlarının artmasıdır. 2008 yılında yaşanan ekonomik kriz, R kuşağı olarak isimlendirilen yeni bir işgücü profilinin ortaya çıkmasına neden olmuştur. $\mathrm{R}$ kuşağı, kriz döneminde yaşanan işten çıkarmalar nedeni ile sorumlulukları artan ve kariyer anlamında daha hızlı gelişen, yüksek vasıflı, iyi eğitimli bir kuşağı ifade etmektedir. Ancak bu özelliklerine rağmen ne unvanlarında ne ücretlerinde ne de yan haklarında bir iyileşme görülmemektedir (Aracı, 2011, s.213). Kriz yıllarında daha fazla çalışma eğiliminin olması, R kuşağının birden fazla kişinin yapabileceği işi tek başına üstlenmesiyle istihdam oranlarında azalma ancak daha fazla çalışma ile de açıklanabilir.

Sermaye yoğun sektörler için kurulan ikinci modelde, yatay kesit bağımlılığı Friedman Testi sonuçlarına göre (0.0000) H0 hipotezi reddedilmiş ve dolayısıyla birimler arasında korelasyon olduğu anlaşılmıştır. Bu nedenle ikinci kuşak birim kök testleri kullanılmıştır. Tablo 9'da Pesaran birim kök testi sonuçları yer almaktadır. Tablo 9'dan da görüldüğü üzere, saat başına ücret ve ihracat oran1 değişkenleri birinci farklardan durağan iken, kişi başına çalışma saati değişkeni düzeyden durağandır.

Tablo 9: Pesaran'ın CADF Birim Kök Testi Sonuçları

\begin{tabular}{|l|lllccc|}
\hline Değişkenler & t-bar & cv10 & cv5 & cv1 & Z[t-bar] & P-değeri \\
\hline KişiBaş. Çalışma Saati I(0) & -2.884 & -2.220 & -2.370 & -2.660 & -3.405 & $0.000^{*}$ \\
\hline \hline Saat Başına Ücret I(0) & -1.490 & -2.220 & -2.370 & -2.660 & 0.640 & 0.739 \\
Saat Başına Ücret I(1) & -2.338 & -2.220 & -2.370 & -2.660 & -1.822 & $0.034^{*}$ \\
\hline İhracat Oranı I(0) & & & & & & \\
İhracat Oranı I(1) & -1.169 & -2.220 & -2.370 & -2.660 & 1.568 & 0.942 \\
\hline
\end{tabular}

Değişkenler durağanlaştırıldıktan sonra analizler tekrarlanmış ve Hausman Testinin sonuçları, $(0.9113>0.05)$ rassal etkiler tahmincisinin tutarlı olduğunu ortaya koymuştur. Sermaye yoğun sektörler için rassal etkiler üzerinden kurulan modelimizde otokorelasyon probleminin var olup olmadiğ Wu'nun LBI testleri ile sınanmıştır. Baltagi-Wu LBI test sonucu (Durbin-Watson $=1.4275801$, Baltagi-Wu LBI $=1.5467511)$ şeklinde olup, her iki test için de değerler 2'den küçüktür. Buna göre test sonucu modelin otokorelasyon problemini içerdiğini göstermektedir. 
Sermaye yoğun sektörler için kurulan Rassal etkiler modelinde birimlere göre heteroskedasitenin var olup olmadığı Levene, Brown ve Forsythe'nin testleri kullanılarak sınanmıştır. Levene, Brown ve Forsythe'nin test istatistikleri, sermaye yoğun sektörler için (W0, W50, W10) $(9,110)$ serbestlik dereceli Snedecor F tablosu ile karşılaştırıldığında, "birimlerin varyansları eşittir” şeklinde kurulan H0 hipotezi reddedilmektedir. Bu durumda kurulan modellerde heteroskedasite olduğu anlaşılmaktadir.

Rassal etkiler üzerinden kurulan model için yapılan testlerin sonucuna göre birimler arası korelasyon, heteroskedasite, otokorelasyon olması nedeniyle düzeltme modeli olarak, "Genelleştirilmiş Tahmin Eşitliği Kitle Ortalaması Modeli" kullanılmıştır. Sermaye yoğun sektörler için elde edilen tahmin sonuçlarına Tablo 10'da yer verilmiştir.

Tablo 10: Sermaye Yoğun Sektörlerde Gelir Düzeyinin Çalışma Saatleri Üzerindeki Etkisi

\begin{tabular}{|l|c|c|}
\hline Bağımlı Değişken: Çalışma Saatleri & \multicolumn{1}{|c|}{$\begin{array}{c}\mathbf{t} \\
(\mathbf{P}>|\mathbf{t}|)\end{array}$} \\
\hline Bağımsız Değişkenler & $\begin{array}{c}\text { Katsayı } \\
\text { (Standart Hata) }\end{array}$ & 2.75 \\
\hline \multirow{2}{*}{ Saat Başına Ücretler } & $\mathbf{0 . 0 2 5 0}$ & $(0.006)^{*}$ \\
\hline İhracat Oranı & $(0.0091)$ & -3.45 \\
& $\mathbf{- 0 . 0 0 0 3}$ & $(0.001)^{*}$ \\
\hline \multirow{2}{*}{ Kriz (Kukla Değişken) } & $(0.0001)$ & 1.36 \\
& $\mathbf{0 . 0 0 9 2}$ & $(0.173)$ \\
\hline
\end{tabular}

*\%0,05 düzeyinde istatistiksel olarak anlamlıdır.

Tablo 10'da verilen analiz sonuçlarına göre 2008 krizinin çalışma saatleri üzerindeki etkisi anlamsız iken saat başına ücretler ve çalışma saatleri arasında istatistiksel olarak anlamlı ve pozitif bir ilişki bulunmuştur. Diğer bir ifade ile sermaye yoğun sektörlerde saat başına ücretlerdeki \%1'lik artış, çalışma saatlerini $\% 0.0250$ yükseltmektedir. Bu durum ikame etkisi olarak adlandırılmaktadır. Buna göre, Türkiye imalat sanayi üzerinden yapılan analiz sonuçları, sermaye yoğun sektörlerde ikame etkisinin geçerli olduğunu, gelir düzeyinde meydana gelen artışların çalışma saatlerini artırdığını ortaya çıkarmıştır.

Tablo 10'da verilen analiz sonuçlarına göre, krizin çalışma saatleri üzerinde istatistiksel olarak anlamlı ve pozitif (0.0092) etkisinin olduğu görülmektedir. Dolayısıyla emek yoğun sektörlerde olduğu gibi sermaye yoğun sektörlerde de, kişilerin kriz yıllarında (2008 yılından sonra) daha fazla çalışma eğiliminde oldukları söylenebilmektedir. İhracat oranı ve çalışma saatleri arasında ise istatistiksel olarak anlamlı ve negatif bir ilişki ortaya çıkmıştır. Analiz sonuçlarına göre, ihracat oranında meydana gelecek \%1'lik artış, çalışma saatlerini \% 0.0003 azaltmaktadır. Türkiye'nin emek yoğun faktör donatımına sahip olması ve üretimde nispeten emeğin daha yoğun kullanılması nedeniyle, ihracat oranlarındaki artış, üretimi arttırırken, buna bağlı olarak daha çok emek yoğun sektörlerde çalışma saatlerini arttırdığı ancak, sermaye yoğun sektörlerde çalışma saatleri üzerinde azalmaya yol açtığı düşünülmektedir.

\section{SONUÇ}

Çalışmada, Türkiye ekonomisinde gelir değişmelerinin ve iktisadi krizlerin çalışanların boş zaman tercihleri üzerindeki etkisi, Türkiye imalat sanayi alt 
sektörleri üzerinden incelenmiştir. Konuyla ilgili literatür incelendiğinde, ekonomik gelişmenin bazı toplumlarda çalışma süresini arttırırken bazı toplumlarda ise boş zaman tercihlerini arttırdığı görülmektedir. ABD'de gelir düzeyindeki artış daha fazla çalışmaya neden olurken, Avrupa'da çalışma süresinin azalması, boş zaman tercihinin artmasına yol açmaktadır. Buna göre, gelir değişmelerinin boş zaman tercihleri üzerinde iki farklı etkisinin olduğu söylenebilir. Boş zamanların fiyatının artması nedeniyle daha az boş vakit geçirmek ve işe daha fazla vakit ayırmak, "ikame etkisi”" olarak ifade edilmektedir. İște harcanan zaman miktarı aynı iken toplam gelir arttığında, bu ilave gelirin bir kısmı daha az saat çalışarak daha fazla boş zaman satın almakta kullanılabilir. Ekonomi açısından normal bir mal olarak kabul edilen boş zaman talebi, gelir arttıkça artmaktadır. Buna bağlı olarak ücret artışıyla birlikte boş zaman talepleri de artacaktır. Bu durum ise "gelir etkisi" olarak adlandırılmaktadır.

Çalışmada, imalat sanayi çalışanlarının gelir düzeylerinin alt gelir grubu ve üst gelir grubu olarak ayrıştırılması amacıyla, imalat sanayi alt sektörleri emek yoğun ve sermaye yoğun sektörler olarak iki kısma ayrılarak ele alınmıştır. Panel veri analizi yöntemi ile gerçekleştirilen analiz sonuçlarına göre, emek yoğun sektörleri temsil eden alt gelir düzeyinde gelir arttıkça çalışma saatleri düşerken; sermaye yoğun sektörleri ifade eden üst gelir düzeyinde ise gelir artışı karşısında çalışma saatlerinin arttığı görülmüştür.

Çalışma, Türkiye'de emek yoğun sektörlerde gelir etkisinin, sermaye yoğun sektörlerde ise ikâme etkisinin geçerli olduğunu ortaya koyarak, aynı toplumda iki farklı eğilimin olduğunu göstermiştir. Gelir değişmeleri boş zaman tercihleri üzerinde Avrupa'da gelir etkisine; ABD'de ise ikâme etkisine yol açarken, Türkiye'de her iki etkinin de yaşandığı ortaya çıkmıştır. Türkiye'de alt gelir grubunda, Avrupa'da olduğu gibi gelir düzeyi arttıkça çalışma süresinde azalma yaşanırken; üst gelir düzeyinde ise ABD'de olduğu gibi gelir düzeyinin artması daha fazla çalışma eğilimine yol açmıştır.

Çalışma, gelir değişmelerinin boş zaman tercihlerini arttırması ya da azaltması yönünde hangi etkiyi ortaya koyacağının, toplumun sahip olduğu gelir düzeyine göre değişeceğini göstermektedir. Konuyla ilgili literatürde boş zaman tercihlerini etkileyen faktörler arasında toplumun sahip olduğu kültür ve dini inançların etkili olduğu üzerinde durulmaktadır. Literatürdeki diğer çalışmalar ile karşılaştırıldığında, bu çalışma, boş zaman tercihlerindeki farklılıkların bir sebebinin de gelir düzeyindeki farklılıklar olduğunu ortaya koyması açısından literatüre katkı sağlamıştır.

\section{KAYNAKÇA}

Aracı, M., (2011). Ekonomik Krizin Yarattığı R Kuşağı ve Çalışma Hayatına Etkileri. Organizasyon ve Yönetim Bilimleri Dergisi, (3) 2, 211-220. http://www.sobiad.org/ejournals/dergi_ybd/arsiv/2011_2/mehtap_araci.pdf

Aytaç, Ö., (2002). Boş Zaman Üzerine Kuramsal Yaklaşımlar. Fırat Üniversitesi Sosyal Bilimler Dergisi, (12) 1, 231-260. http://web.firat.edu.tr/sosyalbil/dergi/arsiv/cilt12/sayi1/231260.pdf 
Alesina, A., Glaeser, E. \& Sacerdote, B. (2006). Work and Leisure in the United States and Europe: Why So Different?. (20), http://www.nber.org/books/gert06-1

Barro, R. J.,\& Mc Cleary, R.M., (2003). Religion and Economic Growth. http://eco.isu.ac.ir/EDU/dlc/2rd/08/instructor/Religion\%20and\%20Economic\%20Growth. pdf

Barro, R. J.,\& Mc Cleary, R.M., (2002). Religion and Political Economy in an International Panel. Nber Workıng Paper Series, Harvard Uiversity. http://www.jstor.org/stable/3838311

Durlauf, S. N., Kourtellos, A. \& Tan, C. M., (2011). Is God in the Details? A Reexamination of the Role of Religion in Economic Growth. Electronic copy available at: http://ssrn.com/abstract=933989

Fellner, A. (2008). Role of culture in economic development: Case study of China and Latin America. Theses and Dissertations Paper 236. University of South Florida Scholar Commons @USF, http://scholarcommons.usf.edu/etd/236

Gratton, C. \& Taylor, P. (2004). The Economics of Work and Leisure. J.T. Haworth \& A.J.Veal (Ed.), Work and Leisure, Routledge Taylor Francis Group

Greif, A., (2006). Institutions and the Path to the Modern Economy. Cambridge University Press.

Guiso,L., Sapienza,P.\& Zingales,L. (2003). People'sOpium? Religion and Economic Attitudes. Journal of Monetary Economics, 50, 225-282. Doi:10.1016/S0304-3932(02)00202-7

Hibbins, R., (1996). Global Leisure. Social Alternatives, (15)1. http://eds.b.ebscohost.com/eds/pdfviewer/pdfviewer?vid=1\&sid=8f77d1f6-9cd0-468987f3-9d94c36944fd\%40sessionmgr101

Huberman, M., (2004). Working Hours of the World Unite? New International Evidence of Worktime 1870-1913. The Journal of Economic History, (64)4, Doi:10.1017/S0022050704043050, 964-1001.

Juniu, S.(2000). Downshifting: Regaining the Essence of Leisure. Journal of Leisure Research, (32) 1.

https://search.proquest.com/docview/201180881/fulltextPDF/DFEEB015F9CE4626PQ/1?accountid $=16595$

Kotler, P., Jatusrıpak, S., \& Maesıncee, S. (2005). Ulusların Pazarlanmas1- Ulusal Refahı Oluşturmada Stratejik Bir Yaklaşım. (2.Baskı), A. Buğdaycı (Çev.), İstanbul: Türkiye İş Bankası Kültür Yayınları.

Kozaryn, A.O. (2011). Europeans Work to Live and Americans Live to Work (Who is Happy to Work More: Americans or Europeans?), J Happiness Stud Resarch Paper,(12), 225-243. DOI 10.1007/s10902-010-9188-8

Michelacci, C., (2007). Why Do Americans Work More Than Europeans? Differences in Career Prospects. CEPR Policy Insight, (12).

Mocan N. \& Pogorelova, L., (2015). Why Work More? The Impact of Taxes, and Culture of Leisure on Labor Supply in Europe. IZA Discussion Paper No. 9281, https://www.econstor.eu/bitstream/10419/114156/1/dp9281.pdf

Monostori, J., (2009). Work, Leisure, Time Allocation, Tárk1 European Social Report. http://old.tarki.hu/en/research/european_social_report/monostory_eng_2009.pdf

Olovsson, C., (2009). Why Do Europeans Work So Little?. International Economic Review, (50) 1, 39-61. http://www.jstor.org/stable/20486853

Prescott, E.C,. (2004). Why Do Americans Work So Much More Tha http://hasslerj.iies.su.se/courses/Riksbank/Papper/Prescott2004.pdfn Europeans?. Federal Reserve Bank of Minneapolis Quarterly Review, (28)1, 2-13.

Pugno, M., (2013). Scitovsky and the Income-Happiness Paradox. The Journal of Socio-Economics, (43), 1-10. http://www.eng.docente.unicas.it/maurizio pugno/.

Roberts, K., (1999). Leisure in Contemporary Society. CABİ Publishing.

Singh, J., (2016). Individual's Choice between Income and Leisure. http://www.economicsdiscussion.net/income/individuals-choice-between-income-andleisure-explained-with-diagram/1196 
Türkkahraman M., (2006). Toplum ve Temel Toplumsal Kurumlar-Kurumlar Sosyolojisine Giriş. Ankara: Alp

Veal, A.J., (2016). Leisure, Income Inequality and the Veblen Effect: Cross-National Analysis of Leisure Time and Sport and Cultural Activity. Roudledge Taylor \& Francis, (35)2, 215-240. http://dx.doi.org/10.1080/02614367.2015.1036104

Weber, M., Parsons, T., \& Tawney, R. H., (2003). The Protestant Ethic and the Spirit of Capitalism, Mineola: Dover.

Wheatley, D. Hardıll, I. \& Phılp, B., (2011). Managing' Reductions in Working Hours: A Study of Work-time and Leisure Preferences in UK Industry. Review of Political Economy, (23)3, 409-420. Doi: 10.1080/09538259.2011.583832

\section{SUMMARY}

The economic structure of societies has an impact on the working hours spent to generate an income. While an increase in income due to more working hours encourages people to work more in societies that generate more income with the same amount working hours, it leads people to work less and increase their leisure time preferences in some other societies. The aim of the study is examine the impact of the change in workers' income and economic crisis in the Turkish economy on leisure preferences through manufacturing sub-sectors of Turkey. In the study, firstly the concept of leisure time is explained, then the relation between income changes and leisure time is established. The effects of the changes during 2003-2015 were tested econometrically by Panel Data Analysis method.

When the related literature is examined, it is seen that while economic development increases the working time in some societies, it increases the leisure time preferences in some societies. While the increase in income level in the US leads to more work, the decrease in working time in Europe leads to an increase in leisure time preference. It can be said that income changes have two different effects on leisure time preferences as "substitution effect" and "income effect". Accordingly, the effect of income changes on leisure time preferences leads to income effect in Europe, but it leads to the substitution effect in the USA.

The manufacturing sub-sectors were included in the analysis in two parts as labour-intensive and capital-intensive sectors. Thus, the income levels of the employees of the manufacturing industry are separated into lower income group and upper income group. According to the results of the analysis, working hours fall as income increases at lower income levels-labour intensive sectors- (income effect) whereas working hours increase as income increases at higher income levels -capital intensive sectors- (substitution effect). Accordingly, in Turkey, while the income effect on labour-intensive sectors appears to be valid, the substitution effect appears to be valid in the capital-intensive sectors.

According to the results, it is found that both effects have also emerged in Turkey. While the increase of income level leads to a decrease in working hours at the lower income group in Turkey like as in Europe, the increase in the level of income leads to more working trends at the upper income level like as in the US. 

ve Boş Zaman Tercihleri İlişkisi

Compared with other studies in the literature, this study contributed to the literature in terms of that reveal one reason for the differences in leisure time preferences is the income level differences. 